\title{
A escrita da cidade partida: identidade e alteridade em Capão Pecado
}

Luciana Paiva Coronel ${ }^{1}$

Imigrantes. Todos nós o somos, hoje. Quando a viagem não nos move é o entorno que nos foge, o que dá no mesmo. Ficamos então parados, com tudo o mais indo, imigrantes a tentar entrar, todos os dias, em nós mesmos.

Elvira Vigna, O que deu pra fazer em matéria de história de amor.

Morar dentro do tema é complicado.

Ferréz

Parte da ficção brasileira contemporânea, marcada no seu todo por um imaginário notadamente urbano, desconhece o estranhamento provocado pelo entorno movediço e opaco, que impede as personagens de reconhecer a paisagem à sua volta e igualmente de reconhecer a si mesmas nas trajetórias que realizam por esse espaço indeterminado. Isso porque as cidades, "tornadas impalpáveis e indistintas pela velocidade, são do domínio de poucos" (Dalcastagnè, 2003, p. 19). Essa ficção não apenas emerge de um território concreto da geografia urbana do país como também o reconstrói dentro do espaço narrativo como agente crucial no processo de construção identitária de seus habitantes. Ela anda na contramão da "desterritorialização", traço da narrativa brasileira do século XXI apontado por diferentes críticos com sentidos específicos na abordagem de cada um deles.

É Ferréz, a partir da publicação de Capão Pecado, em 2000, quem divulga e aglutina um conjunto de autores egressos de regiões urbanas marcadas pela miséria e pelas altas taxas de criminalidade. Com o romance, que aborda a rotina violenta do bairro paulistano Capão Redondo, e as obras coletivas que organiza, inicialmente em números especiais da revista $\mathrm{Ca}$ ros Amigos, lançados entre 2001 e 2004, e por fim no livro Literatura marginal: talentos da escrita periférica, de 2005, ganha força uma vertente literária não apenas enraizada em um espaço de precariedade, como também militantemente voltada a promovê-lo como produtor de cultura. No prefácio

\footnotetext{
${ }^{1}$ Doutora em literatura brasileira e professora adjunta de literatura brasileira na Universidade Federal do Rio Grande (FURG), Rio Grande, RS, Brasil. E-mail: lucianacoronel@furg.br
} 
dessa última obra, o autor define o que entende por literatura marginal: é a literatura feita por minorias, sejam elas raciais ou socioeconômicas. Literatura feita à margem dos núcleos centrais do saber e da grande cultura nacional, isto é, de grande poder aquisitivo. Mas alguns dizem que sua principal característica é a linguagem, é o jeito como falamos, como contamos a história, bom, isso fica para os estudiosos, o que a gente faz é tentar explicar, mas a gente fica na tentativa, pois aqui não reina nem o começo da verdade absoluta (Ferréz, 2005b, p. 12-13).

Impreciso no que diz respeito ao âmbito que caracteriza, o termo "marginal", conforme a concepção daquele que o cunhou, pode referir-se ao autor, às formas de produção ou mesmo à linguagem dos textos, como se viu. Importa, sobretudo, o primeiro item, o que fica claro nos critérios usados para a seleção dos textos, cuja linguagem acaba por exprimir as formas da oralidade da periferia, como decorrência natural da extração social de quem escreve. O segundo item, relacionado à divulgação das obras, é o mais controverso, pois o próprio Ferréz trocou a pequena editora que publicara a primeira versão de seu romance por uma editora maior, fato que evidencia por si só as relações tantas vezes recusadas pelo autor entre a produção cultural da periferia e o mercado de bens simbólicos hegemônico. ${ }^{2}$

O romance Capão Pecado "reterritorializa" a prosa de ficção nacional em uma zona periférica da capital paulista, uma zona "marginal" da cidade, sabidamente o bairro onde o autor reside. Dessa circunstância de origem deriva o teor "marginal" de sua forma, marcada pela oralidade da região de onde parte e cuja feição pretende representar. Para muitos de seus leitores e críticos, Ferréz já não se situa no terreno propriamente ficcional, e sim no terreno da prosa documental ou de forte teor testemunhal. O termo "testemunho", oriundo do trauma causado pelo genocídio da Segunda Guerra Mundial, é indiretamente justificado pelo próprio Ferréz, que atribui ao protagonista de seu romance a fala: "Bom-dia Capão, bom dia Vietnã." (Ferréz, 2000, p. 74), aproximando a violência cotidiana do bairro à catástrofe de um conflito bélico perpetuado.

Identificada com uma espécie de "mutirão autoral", em conformidade com o que Rebecca Atencio (2006) considera traço central do relato testemunhal - o fato de o indivíduo que fala representar por meio de sua voz uma coletividade maior -, a narrativa apresenta na entrada das cinco partes que reúnem os vinte e três capítulos que a constituem depoimen-

\footnotetext{
2 Ferréz também produziu, junto com Sérgio Vaz, fundador da Cooperifa (Cooperativa Cultural da Periferia), e o cineasta Jeferson De, um vídeo exibido no quadro "Brasil Total", do programa Fantástico, da Rede Globo de Televisão, no qual divulgava episódios da vida na periferia.
} 
tos de diferentes referências culturais da região, compondo uma estrutura fragmentária e disjuntiva, ainda que coesa no teor político-ideológico das vozes, todas muito afinadas em torno de um projeto de crítica social contundente. O depoimento de Mano Brown, conhecido vocalista do grupo de rap Racionais MC's, é exemplar nesse sentido:

Sem pretensão, a gente aqui do Capão nunca ia conseguir chamar a atenção do resto do mundo, porque da ponte João Dias pra cá é outro mundo, tá ligado?

Eu nem sei o significado do nome Capão e nem sei por que seria Redondo.

Eu era bem pivetinho e já ligava o nome Capão Redondo a sofrimento, $80 \%$ dos primeiros moradores, ou quase primeiros, eram nordestinos, analfabetos, gente muito humilde, sofredora, que gosta da coisa certa.

Gente igual à minha mãe.

São Paulo massacra os mais pobres e aqui no extremo sul eu aprendi o que é ser preto, pobre, filho de mãe solteira negra, que veio da Bahia com doze anos de idade. Aprendi a não gostar da polícia. [...]

Capão Redondo é a pobreza, injustiça, ruas de terra, esgoto a céu aberto, crianças descalças, distritos lotados, veículo do IML subindo e descendo pra lá e pra cá, tensão e cheiro de maconha o tempo todo (Brown apud Ferrez, 2000, p. 23-24).

A trama narrativa de Capão Pecado mostra-se profundamente sintonizada com o tom do depoimento de Brown, figurando o espaço do Capão Redondo como um universo à parte dentro da geografia da cidade. Ainda que boa parte de seus moradores, incluindo o protagonista Rael, se desloque diariamente para o mundo que fica "da ponte João Dias pra lá", eles constatam existir uma fronteira entre o bairro e o território de "fora", figurado na obra como estrangeiro e hostil:

Não tendo escolha, Rael tomou um banho rápido, se arrumou e foi para o bairro da Liberdade. [...].

Ele tinha nojo daqueles rostos voltados pra cima, parecia que todos eles eram melhores do que os outros. Seu pai, se estivesse com ele, com certeza já teria dito: esquenta não, filho, eles pensam que tem o rei na barriga, mas não passam dessa vida sem os bicho comê eles também. Os mesmos bicho que come nóis come esses filho da puta; lá embaixo, fio, é que se descobre que todo mundo é igual (Ferréz, 2000, p. 34-35).

Não é gratuita a revolta do rapaz, mas produto de preconceitos e discriminações sofridas ao longo de sua existência de jovem da periferia. Em fun- 
ção dessa carga estigmatizante, percebe-se não haver fissuras identitárias nas personagens do romance. Tais personagens não se inquietam consigo mesmas, mas apresentam, ao contrário, uma estabilidade existencial inusitada, construída a partir da referência do espaço que habitam, ainda que haja diferenças em termos de personalidade e perspectivas de futuro para cada um, sobretudo no que toca ao grupo de amigos de Rael, que compõem o eixo da trama.

São estes: os irmãos Will e Dida, que se envolvem na aparente facilidade de ganhos do tráfico de drogas e acabam sendo justiçados; Burgos, também ligado ao crime, mas na condição de justiceiro que trabalha para os traficantes, sendo o executor frio de vários companheiros que ao longo da trama vão desagradando aos donos do espaço; Matcherros, que passa os dias entediado jogando videogame, tornando-se, ao final, um empresário, sem que se se possa entender essa ascensão; e Capachão, que, assim como Rael, trabalha desde cedo em atividades braçais pouco remuneradas, sendo borracheiro e em seguida vidraceiro, enquanto o amigo trabalhava em uma padaria e depois em uma metalúrgica. $\mathrm{O}$ desenlace de ambos, no entanto, é distinto: Capachão torna-se policial, como se verá, enquanto Rael termina morto por Burgos, após assassinar o patrão, que descobrira ser amante de sua esposa.

As oportunidades de realização desse conjunto de adolescentes estão diretamente ligadas à possibilidade de superação da adversidade social e cultural da região, mas, ainda assim, relacionadas a ela. Nem mesmo Capachão, o amigo que reverte pesados dramas familiares tornando-se policial militar, recorta-se ao longo da narrativa de seu entorno de origem. Ouve dos comparsas que é um "Robocop do governo" (Ferréz, 2000, p. 40), mas segue vivendo no Capão e escutando o rap dos Racionais MCs, em cujas letras a polícia é seguidamente criticada pelos arbítrios cometidos contra a população pobre. Apenas no final do enredo, Capachão é visto em ação policial no bairro, usando de violência contra as mulheres e alguns de seus conhecidos. ${ }^{3}$ Nenhum comentário é feito, como se a cena falasse por si mesma, sugerindo que ele passara para o outro lado. ${ }^{4}$

A diferença essencial apontada em Capão Pecado não se coloca, portanto, entre os elementos do grupo, ainda que boa parte da trama explore a divisão dos jovens entre os que trabalham e estudam, grupo ao qual pertencem Rael e Capachão, e aqueles que não fazem nada ou servem ao

3 Cena similar ocorre nos filmes de José Padilha Tropa de elite (2007) e Tropa de elite 2: o inimigo agora é outro (2010), nos quais Mathias, o policial negro, ex-morador da favela, acaba atuando naquele espaço e agindo de acordo com os expedientes brutais que marcam a atuação da polícia ali. No primeiro filme, Mathias é apenas membro da tropa do BOPE, mas no segundo torna-se seu comandante, o que acentua a responsabilidade da personagem na execução das torturas realizadas.

4 O próprio nome da personagem, Capachão, derivado de “capacho", já prefigura o servilismo em seu destino. 
tráfico. Na medida em que mesmo Rael, o mais esforçado dos garotos e o mais inquieto culturalmente, acaba sendo arrastado pela voragem da violência bruta do espaço, todos acabam sucumbindo a uma espécie de destino previamente traçado.

O fator essencialmente produtivo na construção identitária dos moradores do Capão é, portanto, a divisão da cidade em duas partes, reproduzindo a luta de classes clássica na teoria de Marx entre os que detêm o capital e os que estão despojados dele. A alteridade é entendida, assim, como adversária, reproduzindo, em via inversa, a noção predominante no conjunto da sociedade sobre os habitantes da periferia, vistos reiteradamente como ameaça vinda das margens e associada ao crime e à violência. Na sequência do enredo citado, já tendo recebido o salário da mãe, o protagonista volta ao Capão, recuperando, assim, a parte que lhe faltava para voltar a ser ele mesmo:

Conforme o ônibus avançava, ele se sentia melhor, se sentia mais em casa. [...] Entregou o dinheiro para sua mãe, correu para o tanque, lavou o rosto como uma forma de desabafo, como se estivesse se lavando dos olhares daqueles hipócritas. Foi para seu espaço naquela pequena casa, pegou um livrinho de bolso de faroeste e começou a ler. Era uma terapia para ele, uma forma de esquecer aquelas pessoas tão preocupadas consigo mesmas a ponto de não notarem as pequenas coisas, os pequenos momentos, que às vezes trazem tanta felicidade (Ferréz, 2000, p. 35-36).

Não há nenhuma chance de entendimento com os habitantes da zona do asfalto, sugere o narrador do romance, apresentando a visão maniqueísta do protagonista por meio do estilo indireto livre. Sabemos hoje que as identidades culturais não são rígidas, mas, pelo contrário, envolvem negociações de sentido, estando em constante processo de transformação. Ainda que se apresentem como dotados de perfis monolíticos, é efetivamente no diálogo com as referências hegemônicas que se conforma a identidade das personagens de Capão Pecado, o que se depreende com facilidade do diálogo pleno de intencionalidade didática que duas delas estabelecem à certa altura da trama:

Eles tinham que ouvir as ideias do Thaíde: "Sou pobre, mas não sou fracassado." Falta algo pra esses mano, sei lá, preparo; eles tem que se ligá, pois se você for notar, tudo tá evoluindo e os chegado tão lá no mesmo, e não tô dizendo isso porque sou melhor não. Cê tá ligado que comigo isso não existe, mas, na moral cara, esses aí vão ser engolidos pelo sistema; enquanto eles dormem até o meio-dia e fica rebolando no salão, os playbas tão estudando, evoluindo, fazendo cursinho de tudo que é coisa. 


\section{$[\ldots]$}

Então se liga, os playbas têm mais oportunidade, mas na minha opinião, acho que temos que vencê-los com nossa criatividade, tá ligado? Temos que destruir os filhos-da-puta com o que a gente tem de melhor, o nosso dom, mano (Ferréz, 2000, p.117-118).

Mesmo que seja por meio de um processo acentuadamente relacional com os "de fora" que se constrói a matriz identitária das personagens que moram "dentro" do bairro periférico, o criador da obra insiste no fechamento como traço central de seu perfil autoral, afirmando em entrevista concedida à revista Caros Amigos: "Eu escrevo para a periferia, mano, quem lê de fora é bastardo" (Ferréz, 2009, p. 15).

Em outras circunstâncias, o autor contraria a declaração anteriormente feita: "Ainda que eu escreva prioritariamente para minha comunidade, não quero minha literatura no gueto. Quero entrar para o cânone, para a história da literatura como qualquer um dos escritores novos contemporâneos" (Ferréz apud Hollanda, 2008). A contradição do autor, mais do que uma mudança de atitude em relação à cultura hegemônica, revela a intenção de permanência nas margens do sistema cultural como forma de preservação de uma identidade própria e, ao mesmo tempo, a consciência um pouco vaga e não assumida integralmente, da impossibilidade dessa autonomia em plena era do capitalismo global, marcada, segundo Fredric Jameson (2002), pela conversão maciça dos bens culturais em mercadorias lucrativas.

A primeira edição de Capão Pecado dificilmente entrará para o cânone, pois configurava uma versão mais "suja" da obra. Nessa edição havia uma série de fotografias do bairro tematizado no enredo, que funcionavam como ilustração do cenário miserável da favela, parecendo dialogar com um tipo de leitor que carece desse tipo de reiteração por desconhecer a realidade das cenas apresentadas. O prefácio de $\mathrm{Li}$ teratura marginal: talentos da escrita periférica manifesta mais nitidamente esse direcionamento para os setores privilegiados da sociedade, que são confrontados por um tom ríspido de linguagem: "somos marginais mas antes somos literatura, e isso vocês podem negar, podem fechar os olhos, virar as costas, mas, como já disse, continuaremos aqui, como o muro invisível que divide este país" (Ferréz, 2005b, p. 10).

Morador do Capão e promotor incansável de seu desenvolvimento cultural, Ferréz cria uma forma engajada de representação da periferia que instiga à revolta dos oprimidos, nos moldes de uma 
revolução social, e não se coaduna absolutamente com as variadas feições da "desterritorialização" presentes, segundo a crítica, no cenário da literatura brasileira contemporânea. Eurídice Figueiredo, por exemplo, a entende como desenraizamento identitário ocasionado por deslocamento espacial concreto, como as viagens ao exterior presentes em obras como Berkeley em Bellagio e Lorde, de João Gilberto Noll (2002, 2004), Budapeste, de Chico Buarque (2003), Mongólia, de Bernardo Carvalho (2003), Passaporte, de Fernando Bonassi (2001), ou Cordilheira, de Daniel Galera (2008), entre outras que cita. Para a estudiosa carioca,

esta desterritorialização é talvez sintoma de uma mudança de paradigma tanto da literatura brasileira quanto da posição ocupada pelo Brasil e pelos brasileiros no seu estar no mundo. Embora em menor escala que outros países da América Latina, o Brasil, país de imigrantes, começou a produzir emigrantes, que deixaram o país em consequência das diferentes crises econômicas sobretudo a partir de 1980 (Figueiredo, 2010, p. 254).

Já Flora Süssekind identifica a desterritorializacão com a dificuldade de representação do ambiente urbano violento nas formas literárias brasileiras contemporâneas, marcadamente no terreno poético, no qual predominam as formas oblíquas e complexas. Para a pesquisadora carioca, "é fundamentalmente um imaginário do medo e da violência que organiza a paisagem urbana dominante na literatura brasileira contemporânea" (Süssekind, 2005, p. 65). Segundo sua concepção, no terreno ficcional, tende-se, pelo contrário, a um tipo de escrita empobrecida e explícita, de teor meramente documental, que configura uma reterritorialização muitas vezes reforçada por imagens fotojornalísticas que acompanham a trama, diluindo ou mesmo neutralizando o processo narrativo propriamente dito.

Capão Pecado é, seguidas vezes, citado no ensaio de Süssekind, oferecendo exemplo de prosa recente na qual se multiplicam os testemunhos diretos, as histórias de vida e os contrastes urbanos. Assim define o romance a estudiosa carioca: "escrito em linguagem propositadamente de gueto, com material autobiográfico, por um ex-padeiro, filho de motorista de ônibus, morador do bairro Capão Redondo, da zona sul de São Paulo" (Süssekind, 2005, p. 62).

Escapou à crítica a notícia de que apenas a primeira edição do livro de Ferréz saiu com material fotográfico, compondo o que ela chama uma "imposição representacional". A partir da segunda edição (Ferréz, 2005), somente a parte narrativa compõe a obra, o que 
suscita sérios questionamentos acerca do que Süssekind entende por uma "relação de dependência discursiva evidente do modo narrativo com relação à sua contraparte visual" (Süssekind, 2005, p. 61). ${ }^{5}$

Igualmente, a pesquisadora da Casa de Rui Barbosa deixou de atentar para o nexo inequívoco existente entre o teor testemunhal das narrativas contemporâneas e o trauma decorrente da violência sofrida pelos seus autores. Ela aponta no ensaio referido as formas poéticas "oblíquas" como capazes de expressar o estranhamento sentido diante da brutalidade inerente à realidade brasileira atual, mas não percebe a presença do trauma da violência nas narrativas que considera exemplos de "ficção neodocumentalista dos anos 90" (Süssekind, 2005, p. 73). Marcio Seligmann-Silva, estudioso da escrita de teor testemunhal, oferece importante subsídio para a discussão desse tema na obra Capão Pecado:

O conceito de testemunho tornou-se uma peça central na teoria literária das últimas décadas devido à sua capacidade de responder às novas questões (postas também pelos estudos Pós-coloniais) de se pensar um espaço para a escuta (e leitura) da voz (e escritura) daqueles que antes não tinham direito a ela. Daí também este conceito ter um papel central nos estudos de literatura de minorias (Seligmann-Silva, 2009).

Longe de depreciar a obra de Ferréz, portanto, o conceito de testemunho a ele atribuído por Flora Süssekind termina por iluminar inúmeros de seus traços constitutivos, uma vez que o livro "concentra em si uma série de questões que sempre polarizaram a reflexão sobre a literatura: antes de qualquer coisa, ele põe em questão as fronteiras entre o literário, o fictício e o descritivo. E mais: o testemunho aporta uma ética da escritura." (Seligmann-Silva, 2009). Certamente a ética da escritura está presente no romance Capão Pecado, em cujo prefácio uma voz anônima sangra a dor de uma coletividade diante da indiferença do leitor:

As mais belas músicas ou as mais realistas palavras não vão te tirar de tão cômoda vida, pois nada mais faz a menor diferença. Todos veem, mas não querem enxergar que o futuro nos reserva mais dor, e nossa vida é como se estivéssemos sentados olhando pela janela de um avião que está caindo rapidamente. E tudo sempre esteve tão perto e tão longe.

A pobreza aqui é passada de pai pra filho, assim como a necessidade de trabalhar dia e noite para comprar um pão [...]. Embriagados

\footnotetext{
5 Pode-se considerar a existência de duas versões de Capão Pecado como resultado de um processo de negociação ocorrido entre o autor e a nova editora no sentido de viabilizar a comercialização da obra. O cotejo das duas edições renderia interessante estudo sobre a obra e suas relações com o mercado editorial nacional.
} 
continuaremos assim, andando no chão frio com os pés descalços, um sorriso na boca ainda seca da corrida contra a lei. Toda uma nação está olhando por uma janela eletrônica; através dela está o passado manipulado, e o que ninguém vê é a porta que fica ao lado, a porta do futuro, que está trancada pela mediocridade de nossos governantes (Ferréz, 2000, p. 17-18).

O volume Literatura marginal: talentos da escrita periférica traz igualmente na apresentação de Ferréz um texto de inequívoca dimensão ética, presente na perspectiva de transformação social para a qual aponta e em prol da qual se posiciona categoricamente:

O ideal é mudar a fita, quebrar o ciclo da mentira dos "direitos iguais", da farsa do "todos são livres", a gente sabe que não é assim, vivemos isso nas ruas, sob olhares dos novos capitães do mato, policiais que são pagos para nos lembrar que somos classificados por três letras classes: C, D, E.

Literatura de rua, com sentido, sim, com um princípio, sim, e com um ideal sim, trazer melhoras para o povo que constrói esse país mas não recebe sua parte (Ferréz, 2005b, p. 10).

Assim híbridos entre ficção e depoimento são os textos "marginais". Capão Pecado é exemplar dessa proposta, pois apresenta um enredo fictício, ainda que bastante colado à experiência de vida de seu autor, entrecortado por manifestos em prol de uma causa, a afirmação cultural da comunidade de origem. A estranheza que causa advém inicialmente dessa estrutura de composição desalinhavada, na qual cada fragmento é dotado de autonomia de sentido, tendo, inclusive, assinatura própria. Quanto à trama propriamente dita, pode-se considerar que revela forte teor de sexismo e ingenuidade, apresentando, em seu todo, pequena densidade narrativa associada a forte teor descritivo.

O narrador do romance, em terceira pessoa, porém bastante identificado com o protagonista Rael, discute muitos episódios da sociabilidade do Capão, como a violência policial e a brutalidade dos traficantes. Ele tem dificuldades, no entanto, de tornar essas considerações elementos essenciais de sua narrativa. Flávio Carneiro, em análise da produção ficcional de Ferréz, aponta a fragilidade desses comentários, demasiado simplistas e esquemáticos. Ainda assim, considera os méritos de Capão Pecado, apresentando a obra como um "rap em forma de romance" (Carneiro, 2005, p. 219).

Mesmo apresentando limitações previsíveis em autor praticamente estreante, a obra cumpre importante papel no cenário literário nacional, marcado pela pouca representatividade das vozes subalternas, conforme mapeamento realizado por Regina Dalcastagnè (2012). Cabe à crítica 
buscar as chaves da compreensão do tosco romance, que ainda não estão completamente evidentes, apontar as limitações e igualmente as potencialidades do polêmico escritor. O desafio consiste em não reproduzir no terreno literário o estigma indelevelmente presente na vida social brasileira.

Jaime Ginzburg fornece bons elementos para a discussão acerca dos critérios de avaliação da qualidade da produção literária hiperterritorializada dos autores da periferia: "O problema do valor do texto, da relevância da escrita, não se insere em um campo de autonomia da arte, mas é lançado no campo abrangente dos direitos civis, em que a escrita é vista como enunciação posicionada em um campo social marcado por conflitos" (Ginzburg, 2010, p. 2).

Pensando a desterritorialização ficcional exatamente no terreno conflitoso da experiência política, social e cultural mais recente, Regina Dalcastagnè a identifica com o apagamento dos traços individuais das cidades no terreno da ficção brasileira contemporânea. Narradas como construção das próprias personagens, elas são, sobretudo, cidades imaginárias, cidades internalizadas que se apresentam reconstruídas por um olhar eminentemente subjetivo:

A velocidade descolaria os homens da paisagem urbana, lhes arrancaria o chão debaixo dos pés. [...] Personagens desterritorializadas - de identidade embaralhada, ou mesmo apagada -, atravessando cidades desertas, que exibem apenas suas fachadas, como se fossem manchas no horizonte, restos de um filme velho que ficou na memória (Dalcastagnè, 2003, p. 18).

No cenário do capitalismo global haveria ainda, segundo a estudiosa da literatura contemporânea, a desterritorialização decorrente do surgimento de uma paisagem mundializada, padronizada pelos objetos compartilhados nas diferentes áreas do globo, que mobiliariam o cenário da prosa contemporânea. Esse mesmo sentido é atribuído ao termo por Beatriz Resende em "Súbito desaparecimento da cidade na ficção brasileira dos anos 90", no qual comenta: "Produto da grande cidade mundializada, a ficção brasileira traz para o texto uma relação de mão dupla com outras cidades do mundo. A cidade do romance e do conto brasileiro passa a ser qualquer cidade" (Resende, 2002, p. 75).

O cenário do capitalismo tardio é, assim, o de um balcão de vendas ampliado. O espaço urbano é invadido pelos grandes outdoors que promovem uma gama interminável de produtos, difundindo o consumo como principal via de satisfação. É necessariamente desterritorializada a paisagem que coube à literatura mais recente representar. E assim ela vem se mostrando majoritariamente em suas 
páginas. A cidade de Capão Pecado, no entanto, não se apresenta assim, abstraída de traços próprios, sendo a representação específica de uma cidade e, mais ainda, de um bairro da periferia dessa cidade o Capão Redondo paulistano.

Regina Dalcastagnè apresenta ainda um traço da cidade contemporânea de extrema importância para o presente estudo: a segregação, marca da existência daqueles que não são atingidos pela voragem dos tempos, que são impedidos de mover-se, ainda que assistam ao movimento ininterrupto e alucinado das ruas e avenidas à sua volta. É desse tipo de experiência que trata Ferréz em sua obra, que contribui para o alargamento do horizonte de representação da literatura brasileira mais recente, dando voz a um tipo de personagem que pouco figura nas tramas usuais. A própria estudiosa afirma:

Nossas cidades literárias são feitas, na verdade, de ausências: mulheres, pobres, cegos, portadores de deficiências físicas e mentais, velhos, crianças, estão todos de algum modo excluídos das ruas e contornos urbanos que se delineiam nos textos contemporâneos. Nesse sentido, temos um pálido retrato da vida fervilhante, desconfortável e violenta de nossas cidades - por onde as mulheres circulam com suas sacolas, suas pastas e seus bebês [...], por onde os pobres têm de passar, nem que seja só para chegar até o trabalho (Dalcastagnè, 2003, p. 24).

Permitindo que as ausências referidas por Dalcastagnè sejam minimizadas e propiciando o enriquecimento da experiência social da leitura, $\mathrm{Ca}$ pão Pecado desacomoda expectativas e pode decepcionar os leitores menos aptos ao convívio com a voz do "outro" que se rebela e protesta. Somente dessa maneira se pode entender o comentário da crítica Flora Süssekind acerca da linguagem do romance ser "propositadamente de gueto" (Süssekind, 2005, p. 62).

Se é uma espécie de gueto o tema que o autor pretende representar em sua prosa, como criticar o uso da oralidade, das gírias e dos dialetos, instrumentos legítimos de figuração? O problema parece ser o fato de que um autor "filho de motorista de ônibus" (Süssekind, 2005, p. 62), como ressalta a autora do ensaio referido, no qual a biografia familiar de nenhum outro autor é mencionada, venha a tornar-se escritor. Porque, junto com o autor do gueto, vêm as personagens do gueto e a linguagem do gueto. Não poderia ser diferente.

Na medida em que se abrem oportunidades para que os segmentos excluídos se manifestem, a eles cabe definir seus próprios modos de expressão na literatura, na música, onde for. Flora Süssekind, no ensaio "Desterritorialização e forma literária", muitas vezes já referido, justifica ter dedicado 
seu estudo às formas poéticas, a seu juízo oblíquas e complexas e, portanto, interessantes como amostragens da produção literária contemporânea, "e não às letras de rap ou funk, com seu registro do cotidiano violento e excludente nas periferias das grandes cidades do país" (Süssekind, 2005, p. 61). Para a pesquisadora, a cultura popular de periferia tem a marca do mero "registro", nem mesmo como criação ela pode ser identificada.

Diante de tal dicotomização, compreende-se a proposta de Ferréz de utilizar o conceito "marginal" para identificar os textos que escreve e os que divulga, ainda que se saiba ser essa marginalidade um estatuto de difícil manutenção pela própria dinâmica do sistema cultural instituído, muito apto a absorver a "novidade" dos formatos da produção literária e a reconfigurá-los em seu interior. Segundo o autor, essa segmentação não seria uma opção sua, mas derivaria de uma constatação lúcida acerca do funcionamento do campo cultural hegemônico, constituindo igualmente uma resposta à sua dinâmica excludente:

Cansei de ouvir:

Mas o que cês tão fazendo é separar a literatura, a do gueto e a do centro.

E nunca cansarei de responder:

- O barato já tá separado há muito tempo, só que do lado de cá ninguém chegou com a nossa parte, foi feito todo um mundo de teses e de estudos do lado de lá, e do cá, mal terminamos o ensino dito básico (Ferréz, 2005b, p. 13).

A proposta de Ferréz reproduz no terreno literário a cidade partida de que trata Zuenir Ventura (1994), uma cidade cindida pelo muro da desigualdade social, que separa de modo inelutável seus cidadãos em dois universos estanques, uma cidade cuja parte privilegiada alimenta profundo temor da invasão dos "bárbaros", fonte maior do seu mal-estar. Assumindo a voz da periferia ameaçadora, Ferréz mostra-se como o bárbaro que simbolicamente invade a paz e o sossego dos que vivem bem. Ainda assim, é no contato por vezes recusado com estes que se constrói sua identidade autoral.

Érica Peçanha do Nascimento, antropóloga pioneira no estudo da literatura de periferia, confirma, em Vozes marginais na literatura, a perspectiva muito presente nesses textos de confinamento em um âmbito restrito do cenário urbano: "A ideia essencialista de uma cultura da periferia, defendida pelos escritores estudados, e exclusiva dos moradores das periferias, pressupõe um mundo à parte" (Nascimento, 2009, p. 56). Regina Dalcastagnè igualmente aponta essa vontade afirmada de ser um outsider em relação ao sistema literário constituído: 
Ferréz reivindica uma tradição literária "às margens". Nos seus livros e entrevistas, ele insiste em marcar seu vínculo com Lima Barreto, Carolina Maria de Jesus e mesmo João Antônio. Assim, se apresenta não como alguém que almeja ser alçado à posição do "grande escritor universal", mas como aquele que briga nas bordas do campo literário. De algum modo, ele já anunciava isso no primeiro livro, com sua afronta sarcástica ao sistema (Dalcastagnè, 2008, p. 101).

Ainda que sarcástica, a afronta contribui para a conformação de um discurso de afirmação do que é próprio em oposição ao que é, nessa concepção, alheio e mesmo adversário. Essa atitude está presente não apenas nos depoimentos do autor mas também no interior da narração romanesca que encadeia a vida de Rael e seus amigos:

Chegando ao mercado do seu Halim, o pão-duro já o tinha visto de longe e já estava contando o dinheiro para lhe dar. Rael se aproximou e Halim nem o cumprimentou, só entregou o dinheiro e disse que o serviço de sua mãe estava custando muito dinheiro. Rael não respondeu nada, só guardou o dinheiro no bolso, disse obrigada e se retirou. Mas Halim notou algo em seu rosto, algo estranho, talvez tenha visto naquele simples menino periférico um sentimento de ódio puro e tenha sentido por algum momento que um dia o jogo iria virar.

$[\ldots]$

Era constante o pensamento de que seu amigo Cobra estava certo, talvez, se ele descolasse uma granada, era só chegar no mercado do seu Halim e explodi-lo com toda sua ganância, mas como sempre ele relevava e dizia a si mesmo ser loucura tal ato (Ferréz, 2000, p. 35).

Expondo didaticamente a necessidade de "virar o jogo" nem que fosse recorrendo à força, o romance pode ser visto como instrumento de luta a favor da revolução social. Causa certo impacto perceber que nós, leitores, sejamos tomados em algumas circunstâncias como representantes desse sistema opressor, como se depreende dos trechos do prefácio de Ferréz à Literatura marginal: talentos da escrita periférica, sintomaticamente intitulado "Terrorismo literário": "Somos o contra sua opinião, não viveremos ou morreremos se não tivermos o selo da aceitação, na verdade, tudo vai continuar, muitos querendo ou não" (Ferréz, 2005b, p. 9). O autor trata com agressividade o leitor, que julga nesse momento um privilegiado:

Somos mais, somos aquele que faz a cultura, falem que não somos marginais, falem que não somos marginais, nos tirem o pouco que sobrou, até o nome, já não escolheremos o sobrenome, deixamos para os donos da casa-grande escolher por nós, deixamos eles marcarem nossas peles, por que teríamos espaço para um movimento literário? Sabe duma coisa, o mais louco é que não precisamos da 
sua legitimação, porque não batemos na porta para alguém abrir, nós arrombamos a porta e entramos (Ferréz, 2005b, p. 10).

Aspirando a ser mais do que a representação simbólica da experiência de vida em uma região brutalmente inóspita, essa literatura aspira a contrariar o imaginário hegemônico acerca do estatuto do ser periférico, dignificando-o. Por isso Ferréz recorre ao termo "marginal", impregnado de teor pejorativo na linguagem usual, para lançar mão de uma estratégia de deslizamento de sentido, tornando o conceito autorreferido uma espécie de medalha, que se porta com orgulho, principalmente porque se trata de uma identidade compartilhada, carregada do sentido de irmandade.

Paulo Roberto Tonani do Patrocínio, na esteira de estudiosos do tema, apresenta o conceito de "literatura menor", oriundo do estudo de Gilles Deleuze e Félix Guattari acerca da prosa ficcional de Franz Kafka, como ferramenta de entendimento da escrita engajada de Ferréz e sua turma. Mais preciso do que "literatura marginal", o conceito agrega em seu bojo os aspectos políticos, coletivistas e ainda a perspectiva da desterritorialização da língua. Apenas este último traço parece não corresponder ao universo da literatura brasileira de periferia contemporânea, que busca a reterritorialização da língua por meio do reforço do dialeto da região de onde emerge. Paulo Tonani analisa os limites dessa proposta:

No entanto, estabelecer uma fronteira rígida entre os espaços centrais e as esferas marginalizadas a partir do tópico da linguagem resultaria em um procedimento analítico que (re)produziria uma compreensão estigmatizada acerca dessa população. O estigma se dá na busca por uma linguagem que seja própria da periferia, esquecendo-se de que as falas produzidas nas margens são, antes de tudo, heterogêneas e impulsionadas por grupos sociais específicos e dotados de códigos culturais distintos (Patrocínio, 2010, p. 41-42).

Ainda que a possibilidade de uma literatura assim segregada da dinâmica cultural e linguística dominante seja de fácil contestação, a lógica de funcionamento da literatura menor - identificada com a "possibilidade de instaurar a partir de dentro do exercício menor de uma língua mesmo maior" (Deleuze e Guattari, 1977, p. 29) uma rasura de sentido, que a torna apta a construir solidariedade ativa entre os segmentos que dela fazem uso - mostra pertinência insuspeitada para o entendimento da produção literária em estudo, também ela composta por uma "sintaxe do grito" e por formas "despedaçadas" impregnadas do protesto desses segmentos.

Tão focada no coletivo da região de onde emerge, a escrita periférica, inserida no mercado de bens simbólicos (Bourdieu, 1996), acaba por chegar ao público de fora do bairro como um cartão-postal às avessas. 
Identidade e alteridade se desdobram do mesmo processo, aglutinando os "de dentro" em oposição aos "de fora", inimigos - e por vezes nós leitores somos incluídos neste grupo. Em alguns momentos, como no depoimento de Mano Brown já citado, percebe-se que essa fronteira é menos nítida do que se imaginaria: “Estou no momento ouvindo 'Lamento' do Tim Maia [...]. Sei lá qual que é, esse tinha mó cara de Capão Redondo, ó mano. Pode ser pretensão minha, mas eu acho que o Tupac e o Bob Marley também têm a cara da nossa quebrada" (Ferréz, 2000, p. 23).

O músico de soul brasileiro, o rapper norte-americano e o músico de reggae jamaicano têm a "cara" do Capão, porque este deixa de ser um espaço físico para se tornar uma atitude política, mais ampla do que qualquer delimitação geográfica e que está relacionada à promoção dos segmentos marginalizados da sociedade. A periferia paulista torna-se assim um microcosmo capaz de representar uma opressão que lhe transcende. O texto hiperterritorializado ilumina, assim, não apenas a dura existência dos moradores do bairro, mas aquela dos subalternos do mundo global.

Importa vislumbrar esses momentos de superação da fronteira geográfica de pertencimento de Capão Pecado, porque eles permitem que o leitor se inclua na problemática que a obra expõe, não apenas no papel de adversário que ela ocasionalmente lhe destina, mas no papel de cidadão que se importa com o que se passa às margens do espaço urbano, porque, afinal, a cidade é uma só, ainda que seja uma cidade partida.

\section{Referências}

ATENCIO, Rebecca (2006). Dangerous minds: Brazil's escritura da exclusão and testimonio. Hispania, v. 89, n. 2, Madison, p. 278-288.

BONASSI, Fernando (2001). Passaporte. São Paulo: Cosac Naify.

BOURDIEU, Pierre (1996). As regras da arte: gênese e estrutura do campo literário. 2. ed. São Paulo: Companhia das Letras.

BUARQUE, Chico (2003). Budapeste. São Paulo: Companhia das Letras. CARNEIRO, Flavio (2005). A terceira lâmina. In: No país do presente: ficção brasileira no início do século XXI. Rio de Janeiro: Rocco.

CARVALHO, Bernardo (2003). Mongólia. São Paulo: Companhia das Letras.

DALCASTAGNÈ, Regina (2003). Sombras da cidade. Ipotesi, Juiz de Fora, v. 7, n. 2, p 11-28.

(2008). Vozes e sombras: representação e legitimidade na narrativa contemporânea. In: (Org.). Ver e imaginar o outro: alteridade, desigualdade, violência na literatura brasileira contemporânea. Vinhedo: Horizonte.

(2012). Literatura brasileira: um território contestado. Vinhedo: Horizonte; Rio de Janeiro: EdUERJ. 
DELEUZE, Gilles; GUATTARI, Felix (1977). Kafka: por uma literatura menor. Rio de Janeiro: Imago.

FERRÉZ (2000). Capão Pecado. São Paulo: Labortexto. (2005a). Capão Pecado. Rio de Janeiro: Objetiva.

(Org.) (2005b). Literatura marginal: talentos da escrita periférica. Rio de Janeiro: Agir.

(2009). A periferia de São Paulo pode explodir a qualquer momento. $\mathrm{Ca}$ ros Amigos, São Paulo, n. 151, p. 12-17, out.

FIGUEIREDO, Eurídice (2010). Desterritorialização na narrativa brasileira do século XXI. In: Representações de etnicidade: perspectivas interamericanas de literatura e cultura. Rio de Janeiro: 7 Letras.

GALERA, Daniel (2008). Cordilheira. São Paulo: Companhia das Letras.

GINZBURG, Jaime (2010). Linguagem e trauma na escrita do testemunho. Disponível em: <http:/ / www.msmidia.com/conexao/3/cap6.pdf>. Acesso em: 6 jul. 2012. HOLLANDA, Heloísa Buarque de (2008). Intelectuais x marginais. Disponível em <http:/ / www.literal.com.br/acervodoportal/intelectuais-x-marginais-1095/>. Acesso em: 15 jul. 2012.

JAMESON, Fredric (2002). A cultura do dinheiro: ensaios sobre a globalização. Petrópolis: Vozes.

NASCIMENTO, Érica Peçanha do (2009). Vozes marginais na literatura. Rio de Janeiro: Aeroplano.

NOLL, João Gilberto (2002). Berkeley em Bellagio. Rio de Janeiro: Objetiva. (2004). Lorde. São Paulo: Francis.

PATROCÍNIO, Paulo Roberto Tonani do (2010). Escritos à margem: a presença de escritores de periferia na cena literária contemporânea. Tese (Doutorado em Letras) - Pontifícia Universidade Católica do Rio de Janeiro, Rio de Janeiro.

RESENDE, Beatriz (2002). Súbito desaparecimento da cidade na ficção brasileira dos anos 90. In: Apontamentos de crítica cultural. Rio de Janeiro: Aeroplano.

SELIGMANN-SILVA, Márcio (2009). Testemunho da Shoah e literatura. In: JORNADA INTERDISCIPLINAR SOBRE O ENSINO DA HISTÓRIA DO HOLOCAUSTO, 10., São Paulo, 2009. Disponível em: <http://diversitas.fflch.usp.br/files/active/0/ aula_8.pdf>.Acesso em: 4 jul. 2013.

SÜSSEKIND, Flora (2005). Desterritorialização e forma literária: literatura brasileira contemporânea e experiência urbana. Literatura e sociedade, São Paulo, n. 8, p. 60-81.

VENTURA, Zuenir (1994). Cidade partida. São Paulo: Companha das Letras. 
Recebido em dezembro de 2012. Aprovado em abril de 2013.

\section{resumo/abstract}

\section{A escrita da cidade partida: identidade e alteridade em Capão Pecado}

\section{Luciana Paiva Coronel}

Este artigo discute a representação da cidade no romance Capão Pecado, de Ferréz, que contraria a forte tendência de desterritorialização do espaço urbano no terreno ficcional brasileiro por meio de uma narrativa ancorada em zona específica da periferia paulistana, marcada pela violência e pela miséria extremas e configurada como a base de um movimento de autoafirmação da cultura dos segmentos excluídos. Em um texto fragmentário e cru, escrito com a colaboração de lideranças culturais da região, o autor mescla aspectos da ficção e da escrita de testemunho, buscando construir um sentido de comunidade entre os moradores de Capão Redondo, ao mesmo tempo em que lhes opõe ao centro da cidade, onde residem aqueles que, segundo a concepção que rege a construção da narrativa, se beneficiam das iniquidades da ordem vigente.

Palavras-chave: Ferréz, literatura brasileira, experiência urbana, violência, escrita testemunhal, protesto social.

\section{The writing of the broken city: identity and otherness in Capão Pecado}

\section{Luciana Paiva Coronel}

This article discusses the representation of the city in the novel Capão Pecado, by Ferréz. It deviates from the strong tendency of considering all cities alike in the Brazilian fiction scenery by means of a narrative that takes place in a geographical area within the outskirts of São Paulo. This area is characterized by violence and extreme poverty and it works as the headquarters of a movement of self-assurance of the have-nots. The novel brings a broken and raw text, written with the cooperation of cultural leaders of the area. There is a mix of fictional aspects and a great deal of testimony. The author seeks to build a community feeling among the people who live in Capão Redondo and at the same time he opposes the downtown area of the city, where the people who benefit from the inequities of the status quo live.

Key words: Ferréz, Brazilian literature, urban experience, violence, testimonial writing, social protest. 